\title{
DESTINASI WISATA ALAM SUMBER SIRA BERBASIS KOMUNITAS SEBAGAI KEARIFAN LOKAL DI DESA PUTUKREJO, KECAMATAN GONDANGLEGI, KABUPATEN MALANG
}

\author{
${ }^{1}$ Martin Rizaldi, ${ }^{2}$ Anin Lailatul Qodariyah \\ 1,2 Program Studi Pendidikan Sejarah, Universitas Negeri Malang \\ ${ }^{1}$ rizaldimartin158@gmail.com
}

\begin{abstract}
Abstrak
Penelitian ini bertujuan untuk menjelaskan destinasi wisata alam Sumber Sira berbasis komunitas sebagai kearifan lokal di Desa Putukrejo, Kecamatan Gondanglegi, Kabupaten Malang. Metode yang digunakan dalam penelitian ini adalah kualitatif-deskriptif. Pengumpulan data di lapangan menggunakan observasi, dan wawancara formal guna memperoleh data atau keterangan pada wilayah penelitian sehingga dapat diketahui gambaran yang jelas mengenai wilayah tersebut. Metode kualitatif juga menggunakan teknik analisis dengan mengkaji suatu permasalahan dengan lebih mendalam. Sumber data juga menggunakan kajian pustaka yang diambil buku dan jurnal. Kecamatan Gondanglegi mempunyai destinasi wisata berupa wisata alam yaitu Sumber Sira yang terletak tepatnya di Desa Putukrejo, Kecamatan Gondanglegi, Kabupaten Malang. Sumber Sira menjadi salah satu aset potensial desa, hal itu dikatakan potensial karena dimanfaatkan oleh penduduk sekitar untuk menjalani kehidupan sehari-hari. Sumber Sira sendiri dikelola oleh perangkat desa dan pemerintah turut mendampingi dalam pengelolaannya sesuai dengan Undang-Undang Regulasi Pemerintahan Kabupaten Malang. Selain itu, organisasi masyarakat seperti karang taruna juga turut membantu dalam mengelola salah satu aset desa yang ada di wilayah ini. Potensi wisata alam Sumber Sira tersebut diharapkan dapat meningkatkan perekonomian masyarakat Desa Putukrejo.
\end{abstract}

Kata Kunci: Destinasi, Wisata Alam, Kearifan Lokal.

\begin{abstract}
This research aims to explain the community-based natural tourism destination of Sumber Sira as local wisdom in Putukrejo Village, Gondanglegi District, Malang Regency. The method used in this research is qualitative-descriptive. Collecting data in the field using observations and formal interviews to obtain data or information on the research area so that a clear picture of the area can be found. Qualitative methods also use analytical techniques by examining a problem in more depth. The data source also uses literature review taken from books and journals. Gondanglegi District has a tourist destination in the form of natural tourism, namely Sumber Sira which is located precisely in Putukrejo Village, Gondanglegi District, Malang Regency. Sumber Sira is one of the potential assets of the village, it is said to be potential because it is used by local people to live their daily lives. Sumber Sira itself is managed by village officials and the government assists in its management in accordance with the Malang Regency Government Regulation Law. In addition, community organizations such as Karang Taruna also assist in managing one of the village assets in this area. The natural tourism potential of Sumber Sira is expected to improve the economy of the people of Putukrejo Village.
\end{abstract}

Keywords: Destinations, Nature Tourism, Local Wisdom. 


\section{PENDAHULUAN}

Pariwisata adalah sektor unggul guna mengembangkan dan meningkatkan perekonomian masyarakat pada suatu daerah (Murni, dkk, 2019). Pariwisata yang terletak di suatu daerah memiliki tujuan agar dapat mewujudkan kesejahteraan masyarakat. Pengembangan industri pariwisata menjadi suatu hal yang penting untuk dilakukan pada masa sekarang. Banyaknya pengembangan industri pariwisata dapat dilihat dari pesona alam, sejarah, dan budaya. Hal ini memiliki daya tarik sendiri di tengah gencarnya pemerintah melalui Kementerian Pariwisata dan Ekonomi Kreatif mendorong pemerintah daerah untuk pengembangan wisata berbasis kearifan lokal.

Community based tourism merupakan pariwisata berbasis komunitas, dimana masyarakat mempunyai wewenang dan berperan sebagai penentu dalam pengembangan pariwisata tersebut. Masyarakat berperan sebagai penentu dan terlibat mulai dari tahap perencanaan hingga tahap pelaksanaannya. Strategi pembangunan berbasis komunitas merupakan strategi pembangunan masyarakat dimana masyarakat diberikan peran yang dominan untuk mengelola sumber daya yang ada (Murni, dkk, 2019).

Kecamatan Gondanglegi mempunyai destinasi wisata berupa wisata alam yaitu Sumber Sira yang terletak tepatnya di Desa Putukrejo, Kecamatan Gondanglegi, Kabupaten Malang. Wisata alam Sumber Sira dikelola oleh perangkat desa dan pemerintah turut mendampingi dalam pengelolaannya sesuai dengan Undang-Undang Regulasi Pemerintahan Kabupaten Malang. Selain itu, organisasi masyarakat seperti karang taruna juga turut membantu dalam mengelola salah satu aset desa yang ada di wilayah ini. Mereka memiliki semangat gotongroyong yang tinggi, karena motivasi yang digunakan ialah nilai-nilai budaya, lembaga-lembaga agama, dan tradisi yang telah berakar dalam masyarakat. Hal inilah yang mendorong munculnya rasa tanggung jawab para warga desa terhadap kesejahteraan desanya.

Beberapa penelitian sebelumnya yang berkaitan dengan pariwisata berbasis komunitas sudah pernah dilakukan. Penelitian dengan judul "Kapitalisasi Pengelolaan Pariwisata Berbasis Komunitas (Studi Kasus Wisata Sumber Maron Desa Karangsuko Kecamatan Pagelaran Kabupaten Malang)" membahas tentang pengembangan wisata sebagai indikator pemerataan pembangunan melalui percepatan petumbuhan pusat-pusat perekonomian dengan menggali potensi dan keunggulan daerah. Potensi lokal menjadi keunggulan dan identitas dasar dari pariwisata ini. Oleh karena itu, pariwisata ini secara efektif dapat meningkatkan nilai tambah dan daya saing sebagai pencapaian pendapatan berkelanjutan. Hal itu juga yang membuat adanya daya tarik masyarakat untuk ikut berkontribusi dalam kegiatan pengembangan wisata 
tersebut (Nafi'ah, dkk, 2020). Penelitian lainya dengan judul "Stategi Pengelolaan Pariwisata Alam Sumber Maron Berbasis Masyarakat (Studi Desa Karangsuko Kecamatan Pagelaran Kabupaten Malang)" juga terkait pariwisata berbasis masyarakat merupakan suatu konsep pengelolaan pariwisata yang mengutamakan peran aktif masyarakat dan bertujuan untuk memberdayakan dan memberikan kesejahteraan masyarakat tetapi masih menjaga kualitas lingkungan agar tidak rusak. Penerapan pariwisata berbasis masyarakat diharapkan mampu memberikan bermacam manfaat terhadap masyarakat setempat, khususnya peningkatan ekonomi yang kelak akan mensejahterakan hidup, perlindungan terhadap lingkungan, dan perlindungan terhadap kebudayaan dan sosial (Anggraeni, 2020). Kemudian penelitian berjudul "Dampak Pengembangan Pariwisata Sumber Maron Terhadap Sosial Ekonomi Masyarakat Dan Lingkungan" membahas tentang pengembangan pariwisata memiliki dampak yang luas dan signifikan dalam pengembangan ekonomi. Upaya pelestarian sumber daya alam dan lingkungan juga akan berdampak terhadap kehidupan sosial budaya masyarakat, khususnya masyarakat lokal. Pengembangan atau pembangunan pariwisata diharapkan dapat memberikan pengaruh bagi masyarakat untuk mendorong pengembangan sektor yang lain, baik ekonomi, sosial, ataupun, budaya. Dengan begitu, pengembangan pariwisata harus berdasarkan kriteria berkelanjutan yang berarti bahwa pembangunan dapat didukung secara ekologis dalam jangka panjang (Hendrianto, 2018).

Penelitian-penelitian di atas secara khusus berkaitan dengan artikel yang sedang dibahas, tetapi dalam konteks pengembangan destinasi wisata berbasis kearifan lokal dan budaya, penelitian dimaksud masih belum banyak dilakukan. Oleh karena itu penelitian ini mengkaji secara lebih luas tentang potensi wisata berbasis kearifan yang sudah berkembang dan mengakar di masyarakat. Penelitian ini diharapakan dapat menjadi inspirasi bagi pengembangan desa wisata berbasis kearifan lokal, sehingga masyarakat dapat terus terlibat dalam pemertahanan budayanya.

Berdasarkan penjelasan di atas peneliti ingin membahas lebih lanjut tentang potensi wisata budaya dan sejarah di kecamatan Gondanglegi, kabupaten Malang. Wilayah kecamatan Gondanglegi memiliki potensi dalam hal pengembangan wisata berbasis kearifan lokal, karena itu pengembangan destinasi wisata dengan keadaan sosial ekonomi masyarakat Desa Putukrejo patut untuk dilakukan. Penelitian ini bertujuan untuk menjelaskan, sejarah Kecamatan Gondanglegi sebelum adanya destinasi wisata; keadaan sosial ekonomi masyarakat Desa Putukrejo; dan bentuk destinasi wisata Sumber Sira berbasis komunitas sebagai kearifan lokal. 


\section{METODE PENELITIAN}

Metode yang digunakan dalam penelitian ini adalah kualitatif-deskriptif dengan memperlihatkan masalah yang ingin dikaji. Dalam pengumpulan data lpangan digunakan teknik observasi dan wawancara formal guna memperoleh data atau keterangan pada wilayah penelitian sehingga dapat diketahui gambaran yang jelas mengenai wilayah tersebut. Wawancara diartikan sebagai sebuah proses komunikasi interpersonal dengan tujuan yang telah ditentukan sebelumnya, bersifat serius, yang dirancang agar tercipta interaksi yang melibatkan aktivitas bertanya dan menjawab pertanyaan (Stewart \& Cash 1982; Hakim 2013). Sedangkan wawancara formal adalah sebuah prosedur sistematis untuk menggali informasi mengenai responden dengan kondisi dimana satu set pertanyaan ditanyakan dengan urutan yang telah disiapkan oleh pewawancara dan jawabannya direkam dalam bentuk yang terstandardisasi (Singh, 2004; Hakim 2013). Sumber data juga didapatkan melalui kajian pustaka atau studi kepustakaan dimana juga dilakukan studi dokumen (Absor, 2019). Kajian pustaka dilakukan dengan menggunakan sumber referensi dari buku dan jurnal, pengumpulan data dilakukan dengan menelaah buku, literatur, catatan maupun berbagai laporan penelitian yang memiliki kaitan dengan masalah yang ingin dipecahkan (Setyosari 2016; Nazir 1988). Analisis data dilakukan melalui tahapan reduksi data, verifikasi data, dan penyajian data.

\section{HASIL DAN PEMBAHASAN}

\section{A. Sejarah Kecamatan Gondanglegi}

Secara historis, asal mula nama Gondanglegi berasal dari Mbah Sogol, beliau merupakan seorang tokoh masyarakat legendaris yang agamis. Bagi masyarakat Gondanglegi sendiri nama Mbah Sogol sudah tidak asing lagi terdengar oleh masyarakat sekitar karena beliau dikenal sebagai sosok yang pertama kali babat alas Gondanglegi. Masyarakat sekitar disana memiliki suatu legenda kuat terkait nama Gondanglegi yaitu konon katanya dari pohon gondang yang buahnya pahit, tetapi menurut Mbah Sogol buahnya itu terasa legi atau manis. Dan dari cerita tentang buah gondang yang menurut Mbah Sogol rasanya legi atau manis itulah yang kemudian akhirnya dipakai sebagai nama dari daerah Gondanglegi (Azizah, 2017).

Kecamatan Gondanglegi adalah salah satu daerah dari 33 kecamatan yang ada di Kabupaten Malang, Provinsi Jawa Timur. Dengan luas mencapai sekitar 61,03 km² dan berbatasan langsung dengan beberapa wilayah kecamatan-kecamatan yang lain. Di antaranya seperti utara yang berbatasan dengan Kecamatan Bululawang, timur berbatasan dengan Kecamatan Turen, selatan berbatasan dengan Kecamatan Pagelaran, dan di barat berbatasan 
dengan Kecamatan Kepanjen. Letak geografi sebagian desa di Kecamatan Gondanglegi berupa dataran dan sebagiannya berupa lereng. Jadi topografi desa di Kecamatan Gondanglegi ini tergolong dataran dan perbukitan (BPS Kabupaten Malang, 2019).

Sebagai daerah yang topografi wilayahnya berupa sebagian dataran dan sebagian perbukitan, Kecamatan Gondanglegi memiliki pemandangan alam yang indah. Selama berada di Gondanglegi pengunjung dapat menikmati berbagai fasilitas yang telah tersedia, seperti terdapat akomodasi, wisata alam, hingga makanan-makanan khas dari kecamatan ini. Akantetapi, kekayaan alam yang terdapat di Kecamatan Gondanglegi ini belum dengan sepenuhnya dapat dimanfaatkan secara optimal. Oleh sebab itu, sekiranya diharapkan kekayaan alam ini dapat dioptimalkan lagi agar pertumbuhan ekonomi wilayah Kecamatan Gondanglegi dapat berpeluang mengalami peningkatan.

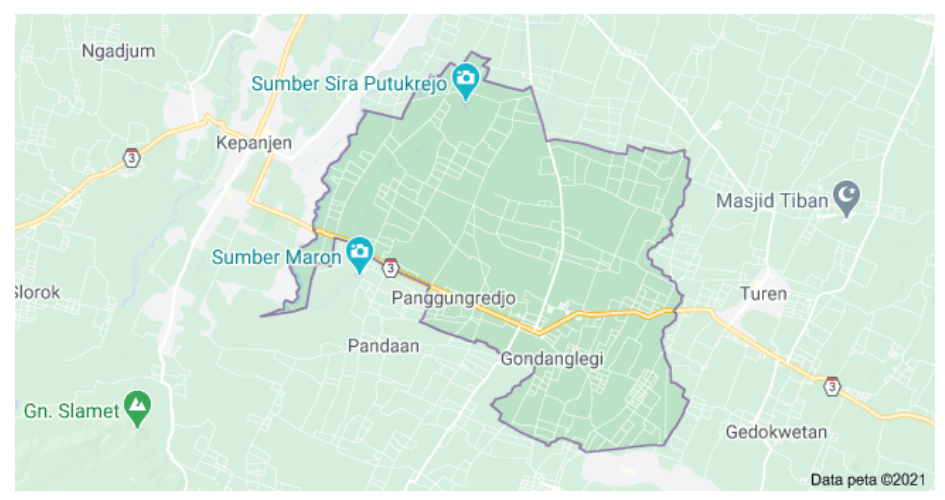

Gambar 1. Peta Kecamatan Gondanglegi

Sumber: Dokumentasi Pribadi

\section{B. Keadaan Sosial Ekonomi Masyarakat Desa Putukrejo}

Salah satu desa yang berada di Kecamatan Gondanglegi yaitu Desa Putukrejo. Luas wilayah Desa Putukrejo adalah 4,28 $\mathrm{km}^{2}$ atau sekitar 7,01\% dari luas wilayah Kecamatan Gondanglegi. Desa Putukrejo berada pada ketinggian 356 meter di atas permukaan laut. Desa Putukrejo juga dikelilingi beberapa desa-desa yang lain, diantaranya seperti di sebelah utara ada Desa Gading, sebelah timur ada Desa Ketawang, sebelah selatan ada Desa Ganjaran, dan sebelah barat ada Desa Sumberjaya. Berdasarkan kondisi demografinya, Desa Putukrejo memiliki 4.598 jiwa penduduk yang dimana terdiri atas 2.284 penduduk laki-laki dan 2.314 penduduk perempuan (BPS Kabupaten Malang, 2019).

Masyarakat Desa Putukrejo memiliki semangat gotong-royong yang tinggi, karena motivasi yang digunakan ialah nilai-nilai budaya, lembaga-lembaga agama, dan tradisi yang 
telah berakar dalam masyarakat misalnya mengajak masyarakat mengenal masalah sekitar mereka yang tengah dihadapi dan membantu mereka mengorganisasikan dirinya sendiri guna menemukan solusi atau pemecahan yang sesuai dengan situasi dan kemampuan. Hal inilah yang mendorong munculnya rasa tanggung jawab para warga desa terhadap kesejahteraan desanya (Ali, 1988).

Penduduk Desa Putukrejo bermatapencaharian sebagai petani dengan mengusahakan tanaman tebu di samping padi dan palawija. Penduduknya kebanyakan merupakan para pendatang dari Madura yang umumnya dari sejak lama secara turun-temurun telah menetap dan bermukim menjadi kelompok besar. Oleh karena itu, dialek Madura juga menjadi bahasa sehari-hari yang digunakan selain bahasa Jawa setempat. Mayoritas penduduk di desa ini adalah beragama Islam dan di desa ini terdapat 55 mushola yang dimanfaatkan untuk melaksanakan kegiatan peribadatan sehari-hari. Dalam hal pendidikan, anak-anak di Desa Putukrejo menempuh pendidikan pada sekolah yang ada di desa tersebut maupun di desa sekitarnya. Lembaga pendidikan yang ada di Desa Putukrejo terdiri dari 3 SD (Sekolah Dasar), 3 SMP (Sekolah Menengah Pertama), dan 3 SMA (Sekolah Menengah Atas). Sedangkan, dalam bidang kesehatan di Desa Putukrejo terdapat 4 Posyandu dan 1 Polindes sebagai sarana kesehatan masyarakat (BPS Kabupaten Malang, 2019).

Desa Putukrejo memiliki potensi yang amat besar dalam berbagai bidang, baik itu dari segi bidang sektor pertanian, peternakan, maupun tempat wisata. Salah satu potensi wisata yang ada di Desa Putukrejo adalah wisata alam Sumber Sira. Potensi wisata alam Sumber Sira tersebut diharapkan dapat meningkatkan perekonomian masyarakat Desa Putukrejo. Tidak hanya dari segi ekonomi tetapi ada juga dari segi sosial, yang dimana diberikan kegiatankegiatan yang dapat mempererat hubungan antar individu yang ada di desa agar kedepannya masyarakat Desa Putukrejo saling bergotong-royong dalam menjaga dan merawat lingkungan sekitar desa mereka.

\section{Destinasi Wisata Alam Sumber Sira Berbasis Komunitas}

Indonesia merupakan salah satu negara yang mempunyai kekayaan alam berupa tanah subur dan air yang begitu melimpah. Salah satu kekayaan alam berupa sumber daya air (SDA) di Indonesia mempunyai peranan penting terhadap kehidupan bagi makhluk hidup. Sumber daya air (SDA) tidak hanya dimanfaatkan untuk dikonsumsi, melainkan dalam perkembangannya sumber daya air sering dimanfaatkan sebagai destinasi wisata. Misalnya, beberapa contoh destinasi wisata yang menjadikan sumber daya air (SDA) sebagai daya tarik 
utama adalah wisata air terjun dan pemandian air panas (Nafi'ah, dkk, 2020). Dalam konteks ini kajian pariwisata penting dilakukan agar potensi-potensi wisata yang ada dapat didayagunakan dengan maksimal dan dapat meningkatkan taraf hidup masyarakat sekitar.

Indonesia sendiri dikenal sebagai negara yang memiliki banyak destinasi pariwisata. Hal itu terbukti seperti yang berada di Provinsi Jawa Timur terdapat potensi tinggi di bidang pariwisata. Salah satu pusat industri pariwisata di Jawa Timur ialah Kabupaten Malang, Kabupaten Malang ini memiliki destinasi wisata yang terletak di Desa Putukrejo, Kecamatan Gondanglegi, Kabupaten Malang yaitu Sumber Sira. Sumber Sira menjadi salah satu aset desa potensial yang berada di Desa Putukrejo, Kecamatan Gondanglegi, Kabupaten Malang. Salah satu aset desa ini dikatakan potensial karena dimanfaatkan oleh penduduk sekitar untuk menjalani kehidupan sehari-hari. Misalnya seperti yang dimanfaatkan oleh para penduduk untuk mengairi sawah irigasi. Sumber Sira ini sekarang telah menjadi lapangan pekerjaan bagi masyarakat sekitar, khususnya penduduk sekitar Desa Putukrejo. Sumber sira memungkinkan akan dapat terus berkembang terlebih apabila salah satu aset desa ini terus dikelola secara profesional dan baik.

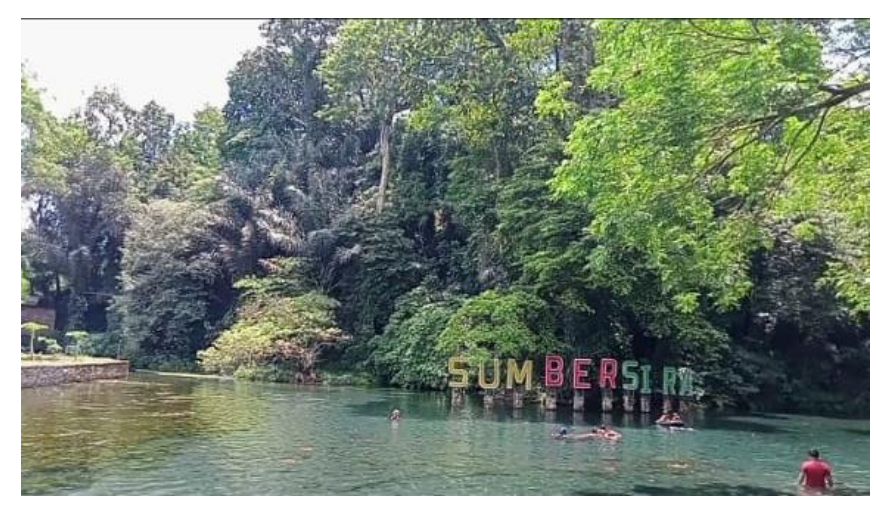

Gambar 2. Wisata Alam Sumber Sira

Sumber: Dokumentasi Pribadi

Sumber Sira merupakan salah satu wisata alam yang berada di Malang bagian Selatan dan daerah kawasan wisata Sumber Sira dikelilingi oleh hutan yang masih alami dan perkebunan seperti tebu atau kelapa, serta ada pula yang menjadi ciri khas wisata alam Sumber Sira yaitu bentangan alam berupa bukit dan juga sawah milik masyarakat sekitar. Airnya berasal dari sumber mata air yang begitu jernih, bahkan ikan-ikan hingga tanaman air didalamnya dapat terlihat dengan jelas. Di dalam kolam Sumber Sira terdapat banyak sekali ganggang hijau dan dasar kolamnya tidak kalah cantik dari pemandangan disekitarnya. Hal ini yang menjadi daya 
tarik wisatawan untuk berkunjung ke tempat wisata alam Sumber Sira karena menyimpan keindahan alam yang khas tersendiri.

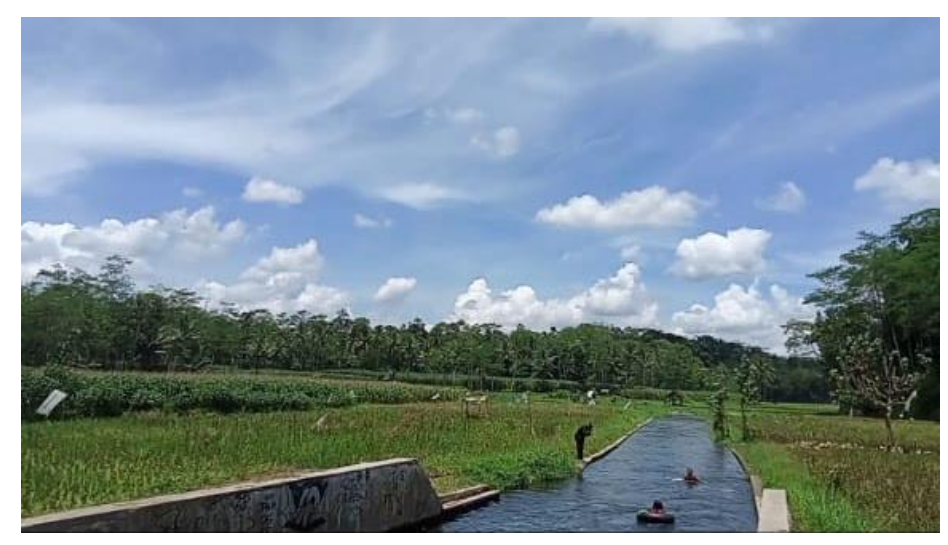

Gambar 3. Pemandangan Alam Sumber Sira

Sumber: Dokumentasi Pribadi

Sumber Sira memiliki pemandangan yang cantik, udara yang segar, serta mata air yang begitu jernih. Oleh sebab itu, maka banyak sekali para wisatawan yang datang untuk mengunjungi tempat ini. Selain itu, di lokasi Sumber Sira juga terdapat banyak pedagang makanan dan beberapa kios-kios yang menyediakan makanan sehingga para pengunjung tidak perlu takut lapar ketika mengunjungi lokasi ini. Untuk fasilitas yang tersedia di antaranya yaitu kamar mandi, musholla, tempat penyewaan alat untuk berendam atau bermain air seperti ban, waterproof, baju renang dan kacamata. Serta terdapat beberapa kios-kios kecil dan pusat kuliner yang menjual aneka makanan. Dan yang baru saat ini terdapat taman yang didesain dengan indah, seperti taman bermain, dan gazebo.

Berdasarkan hasil observasi dan wawancara dengan Bapak Qosim selaku perangkat desa di Desa Putukrejo, menjelaskan bahwa pengelolaan Sumber Sira ini dikelola oleh perangkat desa dan tanahnya disewakan kepada masyarakat untuk berjualan di area sekitar Sumber Sira (Wawacara Personal, 09-09-2020). Kemudian, hasil sewa tersebut digunakan sebagai bantuan dana sosial seperti sumbangan anak yatim dan kegiatan yang ada di desa serta juga menjadi pendapatan tambahan Desa Putukrejo. Saat ini Sumber Sira juga telah difasilitasi oleh pemerintah dan tak hanya perangkat desa yang mengelola Sumber Sira ini, tetapi organisasi masyarakat pun seperti karang taruna juga turut membantu dalam mengelola salah satu aset desa ini. Pemerintah juga turut mendampingi dalam pengelolaan sesuai dengan UndangUndang Regulasi Pemerintahan Kabupaten Malang yaitu membangun ekonomi daerah pada 
sektor pariwisata untuk menjadikan Kabupaten Malang sebagai bumi agro wisata yang terkemukakan di Provinsi Jawa Timur (Wawacara Personal, 09-09-2020).

Selama ini masih belum ada investor yang datang untuk berinvestasi pada kawasan wisata Sumber Sira. Dan pihak desa pun juga tidak berharap dan tidak menginginkan apabila ada investor asing yang tertarik untuk berinvestasi di salah satu aset desa ini. Mereka hanya ingin pihak desa saja yang mengelola salah satu aset desa sumber sira ini yang berada di Desa Putukrejo. Akan tetapi, dalam pengelolaan tersebut masih terdapat kendala seperti kemampuan atau skill masyarakat yang masih kurang dalam pengelolaan aset desa Sumber Sira. Maka dari itu, pihak desa sangat berharap ada universitas atau mahasiswa yang datang untuk mendampingi atau juga memanfaatkan apa saja yang berpotensi di Desa Putukrejo baik itu dari segi bidang pertanian, peternakan dan tempat wisata.

\section{Kearifan Lokal Sebagai Destinasi Wisata Komunitas}

Dalam pengelolaan pariwisata diperlukan komitmen bersama dan tanggung jawab yang profesional, karena itu peran yang sangat strategis dalam pembangunan pemberdayaan komunitas pariwisata sangat strategis untuk terus dilakukan. Kontribusi penting yang dapat dilakukan dalam pengembangan sektor pariwisata adalah pemberdayaan masyarakat atau komunitas lokal berbasis kearifan lokal. Hal ini bertujuan agar tumbuh dan berkembangnya sektor pariwisata dapat mengurangi kantong-kantong kemiskinan yang ada di daerah yang potensial untuk dijadikan kawasan wisata. Dalam konteks ini, masyarakat sekitar seharusnya merasakan efek pariwisata dalam kesehariannya.

Apabila melihat kebiasaan dan pola konsumsi wisatawan terutama mancanegara, sekarang ini banyak bermunculan wisatawan yang minat khususnya berorientasi tidak hanya keindahan alam, tetapi lebih kepada potensi budaya masyarakat maupun alam setempat. Oleh sebab itu wujud dari interaksi wisata itu harus benar-benar maksimal dapat direalisasikan melalui keunikan suatu kawasan yang berbasis kearifan lokal. Desa wisata pada dasarnya mempunyai dua komponen dasar, yaitu akomodasi dan atraksi. Dalam konsep ini akomodasi diartikan sebagai tempat tinggal penduduk yang disewakan kepada wisatawan. Sedangkan attraksi merupakan wujud keseharian penduduk desa serta setting fisik desa yang unik. Kondisi alam pedesaan yang masih alami dengan pertanian tradisionalnya banyak menarik kunjungan wisatawan terutama mancanegara (Ainurrahman, 2010).

Desa wisata merupakan sektor yang potensial untuk dikembangkan karena dapat menjadi salah satu sumber pendapatan suatu daerah. Stimulasi program pengembangan dan 
pendayagunaan sumber daya dan potensi pariwisata yang ada di desa dapat memberikan kesejahteraan hidup dan ekonomi masyarakatnya (Arcana, dkk., 2021). Potensi wisata alam, budaya, dan kearifan lokal masyarakatnya, Desa Putukrejo memiliki peluang yang besar untuk dikunjungi oleh banyak wisatawan. Oleh sebab itu, tata kelola desa yang belum profesional mengakibatkan Desa Putukrejo belum maksimal dikunjungi wisatawan. Tata kelola desa wisata belum bersinergi antar elemen pemangku kepentingan yang saling terkait di tengah masyarakat. Masih banyak terjadinya degradasi kearifan lokal, arah pengembangan desa wisata yang belum memiliki konsep yang jelas. Di samping itu kurangnya pengetahuan untuk melakukan inovasi produk wisata dari pengelola dan masyarakat serta produk wisata yang belum dikemas dengan menarik. Hal ini kemudian berimplikasi terhadap menurunnya tingkat kunjungan wisatawan baik wisatawan asing dan wisatawan lokal.

Upaya untuk memajukan suatu destinasi wisata berbasis kearifan lokal diperlukan adanya pembinaan secara sinergis antara para pelaku usaha pertanian, wisata, dan penerintah. Hal tersebut membuat para pelaku usaha pertanian dan pariwisata akan dapat merencanakan, menyusun, memprogramkan desa wisata berbasis pada kemampuan masyarakat dan potensi desa. Dalam hal ini perlu adanya koordinasi antarpihak yang berkepentingan sehingga dengan terjalinnya koordinasi antarpihak maka tujuan pengembangan desa wisata akan tercapai (Komariah, 2018). Dalam upaya untuk mempertahankan animo pengunjung wisatawan ke Desa Putukrejo, diperlukan adanya penguatan promosi desa wisata. Beberapa hal yang perlu diperhatikan dalam pengembangan desa wisata adalah pengetahuan masyarakat tentang kegiatan wisata, masyarakat harus mempunyai kesadaran dan orientasi bisnis terutama para pengelola wisata, dukungan dari aparatur dan kelembangaan, kuantitas dan kualitas dari obyek wisata, dan tentunya untuk memperkuat promosi adalah dengan adanya katalog desa wisata (Nuurlaily, dkk., 2020).

Dalam konteks pariwisata ini, tantangan yang dihadapi kemudian adalah munculnya upaya untuk mengenalkan kearifan lokal tersebut ke tingkat yang lebih global. Ketika ini dilakukan, maka akan ada penyesuian yang mengakibatkan kearifan lokal tersebut akan berubah demi kebutuhan komunitas global (Arifin \& Ardhiansyah, 2020). Harus ada interaksi antarpemangku kepentingan yang mendukung terbentuknya destinasi wisata berbasis kearifan lokal jika ada perbedaan-perbedaan diantara pemangku kepentingan yang ada. Sehingga terjalin komunikasi dan pengelolaan yang baik dari wisata yang akan dikembangkan. Keterlibatan komunitas adat dan penggiat budaya sangat penting untuk mendukung kebijakan pengembangan desa wisata berbasis kearifan lokal (Bakti, 2018). Sinergi dan kemauan 
berbagau pihak membangun komunikasi dan saling mendukung merupakan kunci sukse dalam pengelolaan destinasi wisata berbasis kearifan lokal.

\section{KESIMPULAN}

Kecamatan Gondanglegi mempunyai destinasi wisata berupa wisata alam yaitu Sumber Sira yang terletak tepatnya di Desa Putukrejo, Kecamatan Gondanglegi, Kabupaten Malang. Wisata alam Sumber Sira dikelola oleh perangkat desa dan pemerintah turut mendampingi dalam pengelolaannya sesuai dengan Undang-Undang Regulasi Pemerintahan Kabupaten Malang. Selain itu, organisasi masyarakat seperti karang taruna juga turut membantu dalam mengelola salah satu aset desa yang ada di wilayah ini. Mereka memiliki semangat gotongroyong yang tinggi, karena motivasi yang digunakan ialah nilai-nilai budaya, lembaga-lembaga agama, dan tradisi yang telah berakar dalam masyarakat. Hal inilah yang mendorong munculnya rasa tanggung jawab para warga desa terhadap kesejahteraan desanya.

Desa Putukrejo memiliki potensi yang amat besar dalam berbagai bidang, baik itu dari segi bidang sektor pertanian, peternakan, maupun tempat wisata. Salah satu potensi wisata yang ada di Desa Putukrejo adalah wisata alam Sumber Sira. Potensi wisata alam Sumber Sira tersebut diharapkan dapat meningkatkan perekonomian masyarakat Desa Putukrejo. Tidak hanya dari segi ekonomi tetapi ada juga dari segi sosial, yang dimana diberikan kegiatankegiatan yang dapat mempererat hubungan antar individu yang ada di desa agar kedepannya masyarakat Desa Putukrejo saling bergotong-royong dalam menjaga dan merawat lingkungan sekitar desa mereka.

\section{DAFTAR PUSTAKA}

Absor, N. F. 2019. Penggunaan Konstruksi dan Konsensus Dalam Kebenaran Sejarah. Prosiding Seminar Nasional Penguatan Riset Dan Luarannya Sebagai Budaya Akademik Di Perguruan Tinggi Memasuki Era 5.0, 304-310.

Ainurrahman, A. (2010). Wisata Berbasis Komunitas. KARSA: Journal of Social and Islamic Culture, 18(2), 136-146.

Ali, M. 1988. Desa Putukrejo, Malang Selatan: Suatu Pembahasan Tentang Motivasi.Unisia, 10(2), 26-59. https://doi.org/10.20885/unisia.vol10.iss2.art3

Anggraeni, R. P. 2020. Strategi Pengelolaan Pariwisata Alam Sumber Maron Berbasis Masyarakat (Studi Desa Karangsuko Kecamatan Pagelaran Kabupaten Malang). Disertasi. Malang: Universitas Muhammadiyah Malang.

Arcana, K. T. P., Pranatayana, I. B. G., Suprapto, N. A., Sutiarso, M. A., Semara, I. M. T., Candrawati, N. L. P. A., \& Suri, M. (2021). Tata Kelola Desa Wisata Melalui Pemberdayaan Masyarakat Berbasis Kearifan Lokal di Desa Tihingan Kabupaten 
Klungklung. Jurnal Abdi Masyarakat, 1(1), 36-45.

Arifin, P., \& Ardhiansyah, N. N. (2020). Penerapan Komunikasi Pembangunan Berkelanjutan Dalam Pengelolaan Desa Wisata Berbasis Kearifan Lokal di Yogyakarta. Jurnal Nomosleca, 6(1), 26-38.

Azizah, E. C. 2017. Implementasi Pelayanan Publik Pemerintah Daerah (Studi Tentang Penyelenggaraan Pelayanan Administrasi Terpadu Kecamatan (PATEN) di Kecamatan Gondanglegi Kabupaten Malang). Disertasi. Malang: Universitas Muhammadiyah Malang.

Bakti, I., Sumartias, S., Damayanti, T., \& Nugraha, A. R. (2018). Pengembangan model komunikasi pariwisata berbasis kearifan lokal di kawasan geopark Pangandaran. Jurnal Kajian Komunikasi, 6(2), 217-230.

BPS Kabupaten Malang, 2019. Kabupaten Malang Dalam Angka. Malang: BPS Kabupaten Malang.

Hakim, L. N. 2013. Ulasan Metodologi Kualitatif: Wawancara Terhadap Elit. Aspirasi, 4(2), 165-172. https://jurnal.dpr.go.id/index.php/aspirasi/article/view/501

Hendrianto, R. D. 2018. Dampak Pengembangan Pariwisata Sumber Maron Terhadap Sosial Ekonomi Masyarakat dan Lingkungan. Disertasi. Malang: Universitas Muhammadiyah Malang.

Komariah, N., Saepudin, E., \& Yusup, P. M. (2018). Pengembangan Desa Wisata Berbasis Kearifan Lokal. Jurnal Pariwisata Pesona, 3(2), 158-174.

Murni, E., Sari, Y. I., \& Hamdani, A. F. 2019. Analisis Pengembangan Wisata Sumber Maron Berbasis Masyarakat di Desa Karangsuko Kecamatan Pagelaran Kabupaten Malang. In Prosiding Seminar Nasional Fakultas Ilmu Pendidikan, Vol. 3, pp. 524-530.

Nafi'ah, Z., Thalita Laras Ayu, D., \& Arvin Praja Kurniawan, R. 2020. Kapitalisasi Pengelolaan Pariwisata Berbasis Komunitas (Studi Kasus Wisata Sumber Maron, Desa Karangsuko, Kecamatan Pagelaran, Kabupaten Malang). Journal of Governance Innovation, 2(1), 68 76. https://doi.org/10.36636/jogiv.v2i1.370

Nazir, M. (1988). Metode Penelitian. Jakarta: Ghalia Indonesia.

Nuurlaily, S., Widyastuty, A. A. S. A., \& Tribhuwaneswari, A. B. (2020). Penguatan Promosi Desa Wisata Berbasis Kearifan di Desa Pujon Kabupaten Malang. Jurnal Penamas Adi Buana, 4(1), 5-12.

Setyosari, H. P. 2016. Metode Penelitian Pendidikan \& Pengembangan. Jakarta: Prenada Media.

Singh, A. K. 1986. Tests, Measurements and Research Methods in Behavioural Sciences. New Delhi: Tata McGraw-Hill.

Stewart, C. J. \& Cash W. B. 1982. Interviewing Principles and Practices. 3rd edition. Iowa: Wm. C. Brown Company.

Wawacara personal dengan Bapak Qosim, tanggal 9 September 2020. 